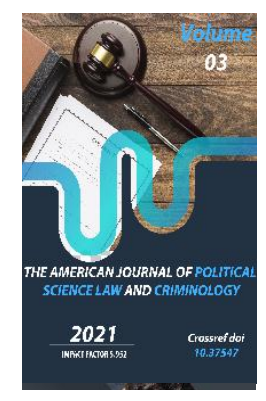

\title{
The Prospects For The Formation Of Public Councils Under The Ministries In Uzbekistan
}

\author{
Azizjon Ergashevich Yuldoshev \\ Associate Professor Of Tashkent State University Of Law, Phd In Law, Uzbekistan
}

Journal Website:

http://theamericanjour

nals.com/index.php/taj

pslc

Copyright: Original

content from this work

may be used under the

terms of the creative

commons attributes

4.0 licence.

\section{ABSTRACT}

In the article author examines the issues of participation of civil society institutions in the formation of public councils under the ministries in Uzbekistan and foreign countries. In the course of the study, the problems of ensuring the openness of the formation of public councils and the absence of a procedure for nominating candidates by civil society institutions and self-nomination of citizens were identified. Based on the results of the study, the author put forward practical recommendations for determining the mechanism of citizens' participation in the formation of public councils and ensuring their representativeness, independence and impartiality.

\section{KEYWORDS}

Advisory body, civil society institutions, civic participation, public control, consultation, lobbying.

\section{INTRODUCTION}

Consultation of public authorities with citizens is recognized as one of the principles of public administration $[1,13]$. Therefore, increasing the efficiency of public councils (PC) under executive authorities both in Uzbekistan and in foreign countries is in the focus of attention of politicians and researchers. The main issues of increasing the efficiency of PC are recognized to ensure their representativeness, balance and independence from the state bodies under which they are created [2, 99; 3, 109-112]. The relevance of these issues for Uzbekistan shows the state and functioning of PC, including under the ministries.

The study of national practice shows the relative passivity of public councils in 
expressing public interests than in other states. For example, according to the results of monitoring carried out in 2019, it was revealed that in some state bodies public councils are just being formed, and most state bodies did not provide information on their activities [4]. In a study conducted in 2020, it was revealed that some shortcomings in the legislation and the administrative and managerial culture that have formed over the years cause certain difficulties for their development.

The relatively passive activity of public councils under the executive authorities in Uzbekistan can be explained by the rather short period of determining the legal basis for their activities. Despite the fact that the first public councils under the executive authorities were officially formed back in 2012 [5], the legal basis for their activities was determined with the Resolution No. RP-3837 of the President of the Republic of Uzbekistan, on July 4, 2018 [6]. This Resolution approved the Model Regulation of public councils under a state body (Model Regulation).

Despite the difficulties in the creation and functioning of public councils under the executive authorities, certain results have been achieved in this sphere. For instance, according to the results of the analysis of the activities of about 20 public councils in 20192020 , it was found that they participated in the discussion of $61 \mathrm{draft}$ laws, $75 \mathrm{draft}$ decrees and resolutions of the President, 139 draft governmental resolutions, 1,930 orders of ministers and departments, heads of regions, 18 resolutions of local Kengashes of people's deputies, 838 resolutions of khokims, made 145 proposals for their improvement, held public discussions of issues on education, ecology, health care, the state of internal roads and other spheres [7].

Polls of the population showed an interest in formation public councils under state bodies, including executive bodies, which proves the need to intensify activities in this direction [4]. To take effective legal and organizational measures to solve them, taking into account a more detailed study of this problem in foreign countries, it will be advisable to conduct a comparative analysis of this issue.

It should be noted that today with various names of public councils and structures similar to activities and procedures of them function under the executive authorities in foreign countries. Therefore, to study them, it is necessary to clarify the concept of "public councils" under the executive authorities and the functions they perform.

An institution called a public council under state bodies as in Uzbekistan exists in Russia, Belarus and several other states. In many foreign countries, institutions similar to them with other names exist and are being formed. For instance, in the USA there are advisory committees, in France - administrative structures of an advisory nature, in the UK advisory Non-Departmental Public Bodies (NDPBs) [8], in Sweden - agencies, commissions [9, 656-657], in the EU - expert groups [10, 71-86], etc. $[11,158]$ All these bodies [12, 1189-1211], including public councils are called advisory bodies [13, 104], which shows the presence of their common features.

A study of the definition of an advisory committee in the United States shows that it includes all advisory bodies, including public 
councils, other permanent and temporary advisory structures under governmental bodies, including expert and working groups. Subject to Part 2, Section 3, Federal Law of the United States, the term "advisory committee" means any committee, commission, council, conference, group, task force or other similar group, or any subcommittee or other subgroup, which is formed by law, reorganization plan, established or are used by the President, one or more agencies in the interest of receiving advice or guidance by them or by federal government officials. This term excludes any committee that is composed entirely of employees of the Federal Government, or formed by the National Academy of Sciences or the National Academy of Public Administration [14].

The definition of an advisory committee in the United States focuses on advising the authority and governmental agencies, which is typical for the UK and most other countries [15,181-198]. In spite of this, the advisory bodies, conveying alternative points of view to the representatives of the authorities, provide an opportunity for all interested parties to participate in the decision-making process [16, 692]. In general, all of them in one way or another through consultations contribute to the relationship between the state and citizens [17, 423], lobbying interests [18, 42-49], civic participation [19, 40-52], public control [20,72], mobilization of various social groups [21, 145$]$.

In addition to performing similar functions, advisory bodies also have common problems. Today, the relative passivity of advisory bodies, lobbying of private interests and the influence of state bodies on them are such problems that need to be addressed. To solve these problems, researchers propose to define the ethical standards of members of advisory bodies [22, 87-88], strengthen their responsibility to citizens [23,1309-1331], revise the existing formation procedures and other recommendations [24, 149-160].

\section{MAIN PART}

In Uzbekistan, in accordance with section 13 of the Model Regulation, membership of a public council under state bodies (public council), as a rule, accepts labor veterans who served exemplary in a state body, authoritative citizens with extensive practical experience in the spheres of public activity, as well as representatives of NGOs, mass media and other civil society institutions [5]. Section 14 establishes that its composition is approved by the decision of the head of the state body every 3 years. The absence of other rules leaves the selection of candidates for members of public councils at the discretion of ministers.

To ensure the objectivity of the formation of public councils, section 7 of the Decree No. DP-61810 the President of the Republic of Uzbekistan, on March 4, 2021, it was established that the composition of public councils is approved by the decision of the head of the state body every two years after agreement with the Public Chamber under the President of the Republic of Uzbekistan, the total number of their members there can be no less than 15 people, at least 50 percent of whom must be representatives of NGOs [25]. However, the procedure for selecting members of public councils and their coordination with the Public Chamber has not yet been determined. 
It is clear that the lack of a procedure for selecting and nominating candidates for members of public council is one of the reasons for not creating them by some state bodies. A study of the websites of all 24 ministries showed that 3 of them contain Regulation on public councils, 3 of them support the tasks they perform, 2 of them contain information about their creation and activities. In addition, only the Youth Uniion [26] has been created in the Ministry of Investment and Foreign Trade, and the Advisory Council on Gender Equality in the Ministry of Economic Development and Poverty Reduction [27]. Also, despite the fact that, according to section 16 of the Model Regulations, information on the composition of the Public Council and the changes made to it within 5 days from the date of their approval must be published on the official website of the state body, this norm has not been implemented, with the exception of the Ministry of Water Resources [28] and Ministry of Justice [29].

At the same time, the Public Council under the Ministry of Water Resources of the Republic of Uzbekistan consists of 9 members, of which 7 are employees of the Ministry, one is an employee of an organization subordinate to him, and the other is the Chief Editor of the magazines "Agriculture and water sector of Uzbekistan" and "Agro IIm", which is violation of legislative acts. Even if the requirements for the composition of public councils are fulfilled, their members cannot be selected by the head of a state body from among loyal NGO representatives, regardless of whether they were established with the participation of the state or independently by citizens.
An important step in achieving objectivity and activeness of public councils was determined in section 4 of the Decree No. DP-6181 of the President of the Republic of Uzbekistan, on March 4, 2021, according to this, the number of representatives of NGOs in public councils shall constitute up to 5 percent in 2021 and 25 percent in 2025. The next step in this direction would be to determine the mechanism of participation of these organizations in the selection of members of public councils.

It should be noted that in order to fill the gap in legislation, the National Movement "Yuksalish" with the support of the United States Agency for International Development (USAID), developed a Methodological Manual for the Creation and Development of Public Councils under the Government of the Republic of Uzbekistan (Methodological Manual) [30]. This manual recommends a detailed procedure for the competitive selection and nomination of members of the public council in 6 stages, specially created for this by the organizing committee and the election commission with the wide participation of NGOs.

At the same time, when studying the Methodological Manual, it was revealed that there were no recommendations for nominating candidates for members of the PC. It is known that not every member of the NGO can participate on behalf of the NGO. These and other questions show the necessity for the most detailed regulation of the formation of public councils.

\section{RESULTS AND DISCUSSIONS}

The absence of a procedure for nominating candidates for members of PC shows a 
violation of the requirements of the law. For instance, when studying the websites of the ministries, no announcements were found about the competition for the selection of candidates for PC, with the exception of the Ministry of Public Education. In this announcement, one of the requirements for candidates is 3 years of experience in civil society institutions in the field of the ministry's activities [31]. it is not required to be a representative of any institution of civil society, which lowers the role of NGOs and other civil society institutions in the activities of public organization.

At first glance, the opinion about the necessity for more detailed regulation of the nomination and selection of candidates by NGOs can be refuted by the US Law on Advisory Committees. FACA only require the membership of the advisory committee to be fairly balanced in terms of the points of view represented and the functions to be performed by the advisory committee [14]. If you study more deeply, it will become known about the compliance of NGOs with the requirements of democracy on the adoption of collegial decisions and, accordingly, the Roberts' rules [32], which defines the procedure for their adoption.

Taking into account the practice of the United States, it is advisable to establish methodological support for the activities of PC, since according to Articles 58 of the Constitution and other norms of the legislation of the Republic of Uzbekistan, the state cannot interfere in the activities of public associations and other NGOs, including determining in the legislation the procedure for nominating candidates to PC. Therefore, the methodological support of the activities of public councils by section 2 of the Decree No. DP-5980 of the President of the Republic of Uzbekistan, on April 16, 2020, is defined as one of the main activities of the Public Chamber under the President of the Republic of Uzbekistan [33]. Consequently, the development of methodological recommendations by the Public Chamber and participation in their development is a legitimate way of regulating the participation of NGOs in the formation of the PC.

The issue of the participation of NGOs in the formation of the PC can be solved by analogy with the nomination of candidates for elective positions by political parties in international and national practice [34, 56-61]. As in most states, in Uzbekistan, for the registration of a candidate from a political party, a protocol, the highest body of a political party, on the nomination of a candidate is required.

To substantiate the above opinion, one can cite as an example the relevant norms of the Law of Kazakhstan "On Public Councils" [35]. According to section 1 of the second part of Article 10 of the Law, the submission of a written proposal to NGOs to nominate a candidate to the Public Council is one of the requirements for participation in the competition. Part 4 and 5 of Article 9 of the Law are also of particular interest, according to which from one legal entity that is a nonprofit organization, only one representative can be elected to the PC, and the same person can be elected as a member of only one PC of the republican level and not more than two times in a row. These norms allow preventing the strengthening of the position of one organization and its lobbying of its interests.

\section{CONCLUSION}


The conducted studies show the necessity for more detailed regulation of the formation of public councils, recommendations for their implementation and law enforcement practice. The results of the study made it possible to draw the following conclusions and recommendations for improving the procedure for the formation of PC under ministries and other bodies.

In Uzbekistan, the requirements of the democracy to the formation of PC are observed, including non-interference in the nomination of NGO candidates for them, taking into account the practice of foreign countries. However, ensuring the effective participation of NGOs in the activities of the PC shows the necessity for its regulation by analogy with the procedure for nominating candidates for elective positions by political parties. Indeed, the requirement to provide the protocol of the highest body of the NGO on the nomination of its representative in the PC will comply with democratic norms.

It would be advisable to limit the election from one legal entity, which is a non-profit organization, in PC can only one representative, taking into account the experience of Kazakhstan. This will contribute to ensuring a balance of interests and making objective decisions by PC.

Restricting the election of the same person as a member of only one PC and no more than two times in a row will also contribute to the effective organization of activities of PC. Taking into account the additional waste of time, finances and other costs, one person will not be able to actively and effectively participate in the activities of several PC.
In order to attract active citizens, an announcement of a competition for the formation of $P C$ is required. In addition, posting information on the composition and activities of PC will provide awareness of citizens and increase their interest in participating in the activities of PC and the state body.

Most importantly, it is necessary to increase the activity of civil society institutions to improve the formation and activities of the PC. The Public Chamber seems to become the leading institution in Uzbekistan.

\section{REFERENCES}

1. Sardaryan H. T. International Perspectives on Public Administration. - Routledge, 2021. - P. 13.

2. Dyakova EG "Honest balance" or independence: problematization of the discourse of deliberative and consultative bodies in the domestic and American administrative traditions // Bulletin of Tom. state un. 2019. No. 438. - $\quad$ P. 99. URL: https://cyberleninka.ru/article/n/chestn aya-sbalansirovannost-ili-

samostoyatelnost-problematizatsiyadiskursa-soveschatelnokonsultativnyh-organov-votechestvennoy-i (accessed date: 15.06.2021);

3. Yuldoshev A., Latipov B. Civil society institutions: Study manual. - Tashkent, 2019.

4. Analysis of the activities of public councils under government agencies, existing problems and their solutions // https://gujum.uz/nntlar-hayoti/davlatorganlari-uzuridagi-zhamoatchilik- 
kengashlari-faoliyatining-ta-lili-

mavzhud-muammolar-va-ularningechimi/

5. The Resolution No. RP-1839of the President of the Republic of Uzbekistan "On the establishment of the public council under the Ministry of Defense of the Republic of Uzbekistan", adopted on October 24, 2012 // https://lex.uz/docs/2267470.

6. The Resolution No. RP-3837 of the President of the Republic of Uzbekistan, adopted on July 4, 2018 // https://lex.uz/docs/3808835.

7. Tashkent hosted the II National Forum of Public Councils // Pravda Vostoka, February 11 , 2021.https://yuz.uz/ru/news/vtashkente-sostoyalsya-ii-natsionalnyforum-obestvennx-sovetov.

8. What is an NDPB? // https://www.gov.uk/guidance/publicbodies-reform

9. Petersson $O$. Rational politics: Commissions of inquiry and the referral system in Sweden. In The oxford handbook of Swedish politics. J. Pierre (Ed.), Oxford: Oxford University Press. - P. 656-657.

10. Tørnblad S. H. The European Commission expert groups - more than expertise // In the Expertisation and democracy in Europe. - London: Routledge, 2017. - P. 71-86.

11. Rhodes M. L., Gerrits L., Eppel E. A. How Complexity Informs Public Policy and Administrative Practice: Selected International Cases // In the Handbook of Public Administration. Fourth edition. - Routledge, 2021. - P. 158.
12. Bressers D. et al. The Contested Autonomy of Policy Advisory Bodies: The Trade-off Between Autonomy and Control of Policy Advisory Bodies in the Netherlands, the United Kingdom, and Sweden //The Palgrave Handbook of Public Administration and Management in Europe. - Palgrave Macmillan, London, 2018. - P. 11891211.

13. Garifullina G. A. Advisory bodies under the executive branch // State Service, No. 5, 2011. - P. 104. URL: https://cyberleninka.ru/article/n/sovesc hatelnye-organy-pri-ispolnitelnoy-vlasti (дата обращения: 15.06.2021).

14. Federal Advisory Committee Act // https://www.gsa.gov/cdnstatic/FACAStatute-2013.pdf

15. Crowley K., Head B. W. Expert advisory bodies in the policy system //Routledge handbook of comparative policy analysis. - Routledge, 2017. - P. 181-198.

16. Dyakova E.G., Trakhtenberg A.D. The role of advisory bodies in the fight against corruption: American and Russian administrative traditions // Actual problems of scientific support of the state policy of the Russian Federation in the sphere of combating corruption. 2019. №1. - P. 692.

17. Van Ballaert B. The European Commission's use of consultation during policy formulation: The effects of policy characteristics //European Union Politics. - 2017. - T. 18. - №. 3. P. 406-423.

18. Perelstein Yu. A. Public and advisory councils under public authorities as a type of interest group // Bulletin of the 
Voronezh State University. Series: Pravo.- 2021. - №. 1 (44). - P. 42-49.

19. Guida E.P. Public Advisory Councils under the Republican Government Bodies as a Form of Citizens' Participation in Deciding State Affairs // Law in the Modern Belarusian Society. Collection of scientific papers. - Minsk, 2015. - P. 40-52.

20. Zubarev S. M. New technologies of social control: reality or illusion? // Bulletin of Perm University. Legal sciences.2019. Вып. 43. С. 72. DOI: 10.17072/1995-4190-2019-43-72-93

21. Rudenko V.N. Advisory public councils: peculiarities of organization and activity // Politex. 2006. No. 3. URL: http://www.politex.info/content/view/ 271/30 (дата обращения: 30.11.2018).

22. Ignatenko V.A. The specifics of the implementation of ethical standards in the activities of members of advisory bodies // International Journal of the Humanities and Natural Sciences, No. 1-3, 2021. - P. 87-88.

23. Martin G., Connolly C., Wall T. Enhancing NDPB accountability: improving relationships with upward and downward stakeholders //Public Management Review. - 2018. - T. 20. №. 9. - C. 1309-1331.

24. Heald D., Steel D. The governance of public bodies in times of austerity //The British accounting review. - 2018. - Vol. 50. - №. 2. - P. 149-160.

25. The Decree No. DP-6181 of the President of the Republic of Uzbekistan "On approval of the Concept for the development of civil society in 2021 - 2025" adopted on $\begin{array}{llll}\text { March } & 4, \quad 2021 & \text { /I }\end{array}$

https://lex.uz/docs/5319760.

26. Youth Council

http://www.mift.uz/uz/menu/sovetmolodezhi

27. Advisory Board on Gender Equality // https://mineconomy.uz/uz/info/3363

28. Composition of the Public Council under the Ministry of Water Resources of the Republic of Uzbekistan // https://water.gov.uz/ru/page/2/83 (посещение сайта 22.06.2021 г.)

29. Composition of the Public Council under the Ministry of Justice of the Republic of Uzbekistan // https://minjust.uz/uz/about/coordinati ons/

30. Creation and development of public councils under state bodies of the Republic of Uzbekistan: a methodological guide. - T., 2021.https://yuz.uz/ru/news/dvijenieyuksalish-podgotovilo-metodicheskoeposobie-dlya-obestvennx-sovetov

31. Selection of candidates for membership in the public council under the Ministry of Public Education has been announced // https://www.uzedu.uz/uz/yangiliklar192.

32. Robert III H. M. et al. Robert's rules of order newly revised. - New York: PublicAffairs, 2020.

33. The Decree No. DP-5980 of the President of the Republic of Uzbekistan "On the establishment of the Public Chamber under the President of the Republic of Uzbekistan" adopted on April 16, 2020 // https://lex.uz/docs/4789930. 
Doi: https://doi.org/10.37547/tajpslc/Volume03Issue06-07

34. Law No. 383-V ZRK of the Republic of Kazakhstan "On Public Councils", adopted on November 2, 2015 // https://online.zakon.kz/Document/?do c_id=36800092\#pos=3;-106.

35. Йулдошев А. Махаллий сайловларда сиёсий партиялар томонидан номзод кўрсатишнинг ўзбек моделини яратиш масалалари // Жамият ва бошқарув, № 4. 2014. - Р. 56-61 (Yuldoshev A. Issues of creating an Uzbek model of nomination of candidates by political parties in local elections // Society and Management, № 4. 2014. - P. 56-61). 